\title{
Cellular Derivatives and Efficacy in Wound and Scar Management
}

\author{
Albertine Lapp ${ }^{1}$, Pascal Furrer ${ }^{1}$, Albert-Adrien Ramelet ${ }^{2}$, Christian Aubort ${ }^{3}$, Pierre Aubort $^{3}$, \\ Philippe Laurent ${ }^{1,4}$, Lee Ann Applegate ${ }^{4,5}$ \\ ${ }^{1}$ Department of Pharmaceutical Sciences, University of Geneva, Geneva, Switzerland; ${ }^{2}$ Office of Dermatology and Angiology, \\ Lausanne, Switzerland; ${ }^{3}$ Sincopharm, Moudon, Switzerland; ${ }^{4}$ Tec-Pharma, Bercher, Switzerland; ${ }^{5}$ Department of Plastic and Recon- \\ structive Surgery, University Hospital, Lausanne, Switzerland. \\ Email: Lee.Laurent-Applegate@chuv.ch
}

Received November $15^{\text {th }}, 2012$; revised December $18^{\text {th }}, 2012$; accepted December $27^{\text {th }}, 2012$

\begin{abstract}
Biologicals have been used for decades in biopharmaceutical topical preparations. Because cellular therapies are routinely used in the clinic they have gained significant attention. Different derivatives are possible from different cell and tissue sources, making the selection of cell types and establishment of consistent cell banks crucial steps in the initial whole-cell bioprocessing. Various cell and tissue types have been used in treatment of skin wounds including autologous and allogenic skin cells, platelets, placenta and amniotic extracts from either human or animal sources. Experience with progenitor cells show that they may provide an interesting cell choice due to facility of out-scaling and known properties for wound healing without scar. Using defined animal cell lines to develop cell-free derivatives may provide initial starting material for pharmaceutical formulations that help in overall stability. Cell lines derived from ovine tissue (skin, muscle, connective tissue) can be developed in short periods of time and consistency of these cell lines was monitored by cellular life-span, protein concentrations, stability and activity. Each cell line had long culture periods up to 37 - 41 passages and protein measures for each cell line at passages 2 - 15 had only 1.4-fold maximal difference. Growth stimulation activity towards two target skin cell lines (GM01717 and CRL-1221; 40 year old human males) at concentrations ranging up to $6 \mu \mathrm{g} / \mathrm{ml}$ showed 2-3-fold (single extracts) and 3-7-fold (co-cultured extracts) increase. Proteins from co-culture remained stable up to 1 year in pharmaceutical preparations shown by separation on SDSPAGE gels. Pharmaceutical cell-free preparations were used for veterinary and human wounds and burns. Cell lines and cell-free extracts can show remarkable consistency and stability for preparation of biopharmaceutical creams, moreover when cells are co-cultured, and have positive effects for tissue repair.
\end{abstract}

Keywords: Biological; Wound Healing; Scars; Cell-Free Derivatives

\section{Introduction}

Cell-based therapies have been used routinely in medical care for burn and wound management of skin for over 30 years. They offer the promise of repairing and/or replacing damaged tissue and restoring lost functionality because ideally they provide all of the factors necessary for wound healing. Several cell types and tissues have been proposed as starting material including autologous cells, adult stem cells, embryonic stem cells and tissues from placental and amniotic fluid and can originate from human or animal source. Some of these cell types have been used for biological preparations used in processing vaccines, medicinal, cosmetic and tissue engineering products and various skin affections that are targeted include acne scars, after-laser treatments, anti-aging, burns and wounds of all nature [1-10].
Considerable interest and research has been dedicated to the understanding of tissue repair and the associated process. Whereas adult cutaneous wounds heal more slowly and with scar formation to restore tissue integrity, fetal skin, in utero, is observed to have rapid and scarsless tissue repair characterized by regeneration of an organized dermis with normal appendages and by a relative lack of inflammation [11-13]. Fundamental differences between fetal and adult skin and the fetal and adult skin wound environment may be important in inducing efficient tissue repair. From these observations, it was proposed that fetal cells or progenitor cells of certain origins and gestational ages would be efficient in acute and chronic wounds. Indeed, it has been shown that efficient repair could be obtained in 2nd and 3rd degree burns in children [14], acute wounds [15] and in chronic wounds [16] to date and the whole-cell bioprocessing 
and age of the cells were very important aspects $[17,18]$.

Establishment of cell banks is a crucial step in the process of many vaccines, medicinal products or tissueengineering products and therefore the choice of celltype is extremely important. Progenitor cells are differentiated cells with high expansion, regeneration and low immunogenicity properties which have been implicated in efficient tissue repair. Unlike stem cells, they do not require feeder layers or extensive growth factors for expansion which is a major reason for their consistency in scaling out.

Embryonic Stem Cells (ES) are isolated from earlystage embryo in the first cell divisions but there are only several hundred cells as starting material. Stem cells, whether embryonic or adult, are technically very demanding. Maintenance and expansion of adult stem cells in an undifferentiated state require the addition of many specific growth factors [2] and use of feeder layers can cause inconsistent colony cell growth [17]. The necessity to use many exogenous growth factors is also a limiting factor for the scale-up of stem cell cultures for biopharmaceutical preparations and clinical applications. Thus, progenitor cells with their high expansion, simple culture conditions and low immunogenicity properties [18] are ideal conditions for whole-cell bioprocessing destined for cell therapy, tissue-engineering, and cell-free derivatives that can be used for cosmetic and medicinal products.

Preparations from living cells and their delivery to the patient is a major complication for treatment and the shelf-life is very limited with such preparations. Many products for skin repair have applied alternatives such as freeze-dried, frozen and refrigerator stocking [19-25]. Herein, we have looked at in vitro stability (cell life, total protein, biological activity) of ovine progenitor cells to see if they meet the exigent and stringent technical aspects for development of stable formulations. In vivo, we have evaluated cell-free derivative integration and stability for biopharmaceutical preparations (different combined cell-free sources and concentrations) in an oil-inwater cream as an alternative topical delivery system for irritated skin conditions that are frequently presented to the pharmacy (preliminary assessment of biopharmaceutical preparation for veterinary and human cases of noncomplex wounds and burns).

\section{Materials and Methods}

\subsection{Cell Line Development and Cell Banking}

Cell lines were developed from specific tissues of ovine skin, muscle and connective tissue that were obtained from the State Veterinarian before 1998 when no relevant ovine diseases were present on Swiss territory. Cell lines were developed in 1994 and processed as described. Three $1-4 \mathrm{~cm}^{2}$ biopsies from each tissue (skin from the abdominal region; muscle from the thigh; connective tissue from the diaphram) were obtained from 4 different gestational ages to compare growth characteristics $(3,6,9,12$ weeks). Biopsies were cleaned of adherent tissue, washed three times for 15 minutes each in Phosphate Buffered Saline (PBS: $\mathrm{NaCl} 6.80 \mathrm{~g} / \mathrm{l}, \mathrm{Na}_{2} \mathrm{HPO}_{4} 1.48 \mathrm{~g} / \mathrm{l}$, $\mathrm{KH}_{2} \mathrm{PO}_{4} 0.43 \mathrm{~g} / \mathrm{l}$ ), cut into $1-2 \mathrm{~mm}$ pieces and put into culture in tissue culture grade plates $(60 \mathrm{~cm}$, Falcon). Once the adherent cells reached $80 \%$ confluence $(\sim 1$ week), they were trypsinized (EDTA and Trypsin solution, Gibco), amplified and ampoules of cells in $1 \mathrm{ml}$ of freezing medium (50\% DMEM, 40\% FCS, 10\% DMSO) were stored in liquid-nitrogen (Master Cell Banks, 100 ampoules with $5 \times 10^{6}$ cells each). Cell banks were stored in the vapor liquid nitrogen storage vessels (Carbagas). Working Cell Banks (WCB, 50 ampoules with $5 \times 10^{6}$ cells each) were developed from each of the MCB ampoules of cells and stored at $-80^{\circ} \mathrm{C}$ and renewed each year. Long-term stocks were kept in liquid nitrogen.

\subsection{Cell Line Testing}

Safety testing for developed cell banks were controlled for mycoplasma (PCR) and bacterial contamination (specific media test for 7 days in culture). Antibodies towards prions, were tested on each cell bank as follows: for prp protein detection (detection of the sequence DYEDRYYRE in the prion protein) on cell cultures of fetal ovine cells, non-specific binding was blocked by an incubation for $2 \mathrm{hr}$ at $25^{\circ} \mathrm{C}$ with a solution of PBS containing 5\% fetal calf serum (FCS), 7\% normal goat serum (NGS) and $0.1 \%$ Triton $\times 100$. Tissue sections were then incubated overnight at $4^{\circ} \mathrm{C}$ with prp specific antibodies against (6H4 monoclonal antibody, PRIONICS, Switzerland) at a 1:10,000 dilution in PBS containing 5\% FCS, $5 \%$ NGS and $0.1 \%$ Triton $\times 100$. The following morning, fixed cells were washed 3 times for $10 \mathrm{~min}$ each in PBS and the sections treated with biotinylated goat anti-rabbit antibody at 1:200 in a solution of PBS with $5 \%$ FCS, $1 \%$ NGS and $0.1 \%$ Triton $\times 100$ for $3 \mathrm{hr}$ at $25^{\circ} \mathrm{C}$. Tissue sections were washed 4 times for $5 \mathrm{~min}$ each in PBS and then treated with Vectastain $A B C^{\circledR}$ (Vector, Burlingame, $\mathrm{CA}$ ) as indicated by the company for $3 \mathrm{hr}$ at $25^{\circ} \mathrm{C}$. After this incubation, tissue sections were washed 3 times for 10 min each in PBS and treated

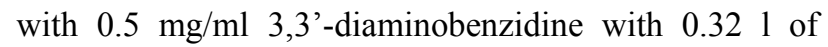
$30 \% \mathrm{H}_{2} \mathrm{O}_{2}$ added just before an incubation of $1-2 \mathrm{~min}$. All samples were treated at the same time. Control samples were accomplished with each experiment and consisted of non-specific IgG fractions of serum. The antibody staining for prp protein using this antibody is represented by a very strong cellular brown coloration. The samples were washed for $5 \mathrm{~min}$ under running water and mounted with Merckoglas ${ }^{\circledR}$ (Merck, Switzerland). 


\subsection{Life-Span of Cell Lines}

The entire life-span of each cell line (skin, muscle and connective tissue) was determined to define limitations of cell bank usage and cellular stability to assure that the starting material for further cell-free extracts would be of high quality. Cellular life-span was defined as the number of in vitro passages until the growth rate was reduced to $25 \%$ of the initial maximum growth rate. Three independent cell cultures (A, B and C), were serially cultured in monolayer from passage 3 to 41 . Each week using the previous passage, 3 new culture flasks with 3000 cells per $\mathrm{cm}^{2}$ were prepared for a total of $40-41$ weeks. Cell number was manually counted after 7 days of culture for each passage.

\subsection{Consistency of Protein Concentration at Different Passages}

To investigate potential variation of total protein through cellular aging (passing the cells), protein concentrations were measured in each of the cell lines at passages 2, 6, 10 and 15. Cellular morphology was also controlled by photography at each cellular passage for comparison. Fetal cell extracts were obtained by 5 complete freezethaw cycles of each cell line. In short, extracts were made at a concentration of $1 \times 10^{6}$ cells $/ \mathrm{ml}$ and placed at $-80^{\circ} \mathrm{C}$ to freeze and $37^{\circ} \mathrm{C}$ to thaw for a total of 5 cycles and centrifuged to remove cellular components. Cell burst was monitored my light microscopy and extracts were also placed into culture to assure that no cell growth remained. Protein concentration was measured with the Bradford Assay (Biorad, Switzerland) and the protein determinations were measured spectrophotometrically with an ELISA plate reader at $595 \mathrm{~nm}$ (Biorad, Switzerland).

\subsection{Biological Activity of Cell-Free Extracts Individually and Combined}

Biological activity of the cell-free extracts was tested for stimulation of growth of established human skin cell lines obtained from cell depositories (American Type Culture Collection). Cell-free extracts were tested individually or combined together (skin, muscle or connective tissue) at various concentrations as follows: $0,1.2,2.5,3,3.5,4$ and $6 \mu \mathrm{g} / \mathrm{ml}$. Extracts were added to the culture medium of two different adult skin cells used as target cell lines (GM01717 and CRL-1221, both 40-year-old male). The number of cells from each of the target skin cell lines was counted manually in triplicate using a hemocytometer after 4 days of stimulation with extracts at various concentration to determine if extracts could stimulate older skin cell growth.

\subsection{Cream Formulation}

Different concentrations ( 2 to $6 \mu \mathrm{g} / \mathrm{ml}$ ) of single and combined progenitor cell-free extracts have been used mixed in an oil-in-water emulsion (cream) to see if longterm stability could be improved. The cream was prepared under controlled, clean-room conditions in an automated pharmaceutical machine (Moltomat, Krieger AG, Basel, Switzerland). Its composition was stated on the external label and contained hydrogenated vegetable oil, glycerine, propylene glycol, cetearyl, ethyhexanoate, decyl oleate, ceteanyl alcohol, cetyl palmitate, glucose, ascorbyl palmitate, tocopheryl acetate, propylparaben, methylparaben, potassium chloride, magnesium chloride, sodium cetearyl sulphate, simethicone. During the preparation of the cream, ovine extracts have been added in different concentrations to the mixture and subjected only to mixing so an even distribution of the extract could be assured. Samples for quality control with respect to microbiological and physico-chemical (viscosity, $\mathrm{pH}$, conductivity, mass volume, colorimetry, microscopy) analyses were sent to the Laboratory for Analyses (Sincopharm, SA, Moudon, Switzerland) at the beginning and end of study date (1 year). Hereafter, this preparation will be nominated Pharmaceutical cream preparation as it was considered as a preparation in small quantities in the Pharmacy under (Good Laboratory Practices) GLP conditions at the time of this study.

\subsection{Extraction and Stability of Proteins in Pharmaceutical Cream Preparation}

Cell-free extracts were incorporated into the cream preparation described above to give $170-340 \mu \mathrm{g} / \mathrm{ml}$ of total protein. Proteins were either separated by ultra-centrifugation and concentrated by dessiccation with silica gel, separated from the cream using a Bio-rad "ReadyPrep, clean-up kit" (Biorad, Switzerland), or extraction by SDS $(1 \%-10 \%)$ directly. Proteins were extracted at 2, 4, 6 and 12 months following incorporation into cream base in triplicate. Protein separation and stability was examined by SDS-PAGE electrophoresis on $4 \%-20 \%$ TrisHCL polyacrylimide gels (Biorad, Switzerland). Preparation at final concentrations of $2-6 \mu \mathrm{g} / \mathrm{ml}$ was tested for overall stability following one year.

\subsection{Clinical Case Reports: Human and Veterinary}

Typical clinical cases that arrive in a pharmacy setting (rural Switzerland) representing wounds and burns are presented for humans and acute wounds for veterinary.

Pharmaceutical cream application and bandaging with gauze was accomplished for patients and bandages were changed either every day (Patients 1 and 3) or every 3 days (Patient 2). Veterinary cases had cream application 1 - 2 times daily for the duration of the treatment (when wounds closed). Gauze bandages could not be easily 
applied to most veterinary cases due to anatomical site of wounds.

\section{Results}

\subsection{Cell Banking (MCB and WCB Production)}

Cells were passaged one time following tissue explants and cells from passage 1 were then used to establish Master Cell Bank (MCB). Each ampoule of cells in the MCB was mixed to assure consistency and that each was identical for the 100 vials of cells. Ampoules of cells from the MCB were then expanded by serial subculture up to passage number two and pooled for distribution into ampoules to form the Working Cell Bank (WCB), for which vials were then used for experimentation for these studies. The WCB generated consisted of 50 ampoules with 5 million cells in each for the skin, muscle and connective tissues at passage 2 in triplicate samples.

\subsection{Life-Span of Cell Lines}

Actual cell counts were conducted each week with two media changes for cell culture flasks of cells from each cell line (skin, muscle and connective tissue) after 7 days of cell growth at an initial concentration of 3000 cells $/ \mathrm{cm}^{2}$ and in triplicate. Each week using the previous passage,
3 new cell culture flasks with this concentration were prepared for a total of 41 weeks. Stable populations were seen up to passage 33 for skin and muscle cells and 35 for connective tissue cells where cell number decreased to $\sim 50 \%$ of initial cell number (Figure 1). It is necessary to establish the most efficient cell-life by using the minimum number of initially-seeded cells which will permit the maximum production of a finished product at the passages permitted (less than $2 / 3$ the life of the cell line under specific conditions). Cells from ovine tissues used herein could be easily used to passage $33-35$. The cell banks developed with ovine tissues are only needed between passages 3 - 8 for out-scaling due to their high growth capacity and therefore fit well within the established model for cell-free derivative product production.

Life-span of each cell line (skin, muscle, connective tissue) was determined to define limitations of cell bank usage. Three independent cell cultures (A, B and C), were serially cultured in monolayer from passage 3 to 41 and cell number was manually counted after 7 days of culture for each passage.

\subsection{Consistency of Protein Concentrations between Cellular Passages}

From the original tissues, 3 different sub-cultures and
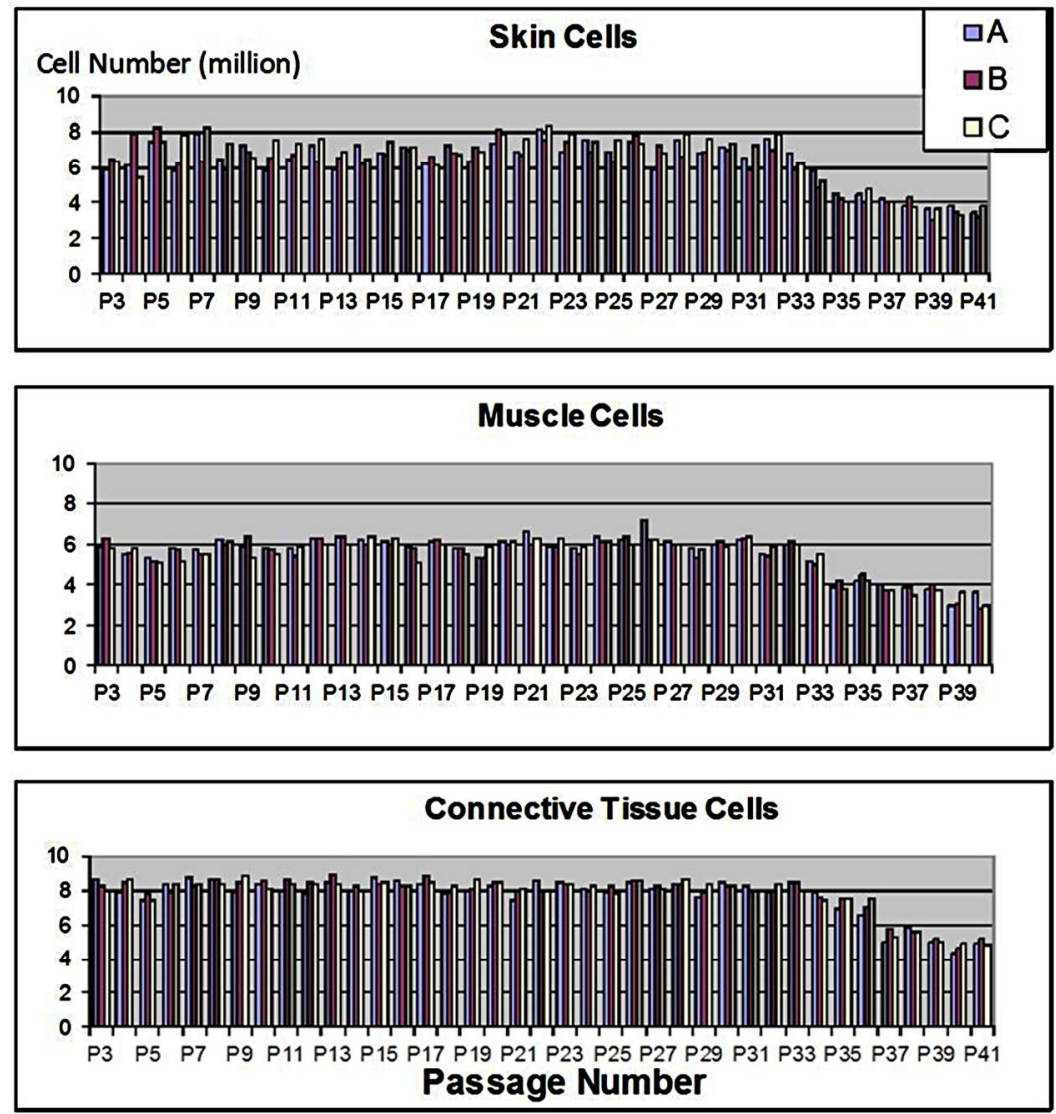

Figure 1. Growth survival of progenitor cells. 
cell lines were developed and each of these were tested in triplicate for protein concentration (Figure 2). Protein concentration was measured in the freeze-thaw and centrifuged extracts of the three independent cell cultures (A, $\mathrm{B}, \mathrm{C})$ from flasks seeded at $3000 \mathrm{cells} / \mathrm{cm}^{2}$ from passage $2,6,10$ and 15 . Protein was then extracted from one million cells from each sub-culture in triplicate. The range mean protein concentrations were $0.12-0.21 \mathrm{mg} / \mathrm{ml}$ at passage 2 and $0.20-0.24 \mathrm{mg} / \mathrm{ml}$ at passage 15 . There was low variability between the three independent cultures $\mathrm{A}, \mathrm{B}$ and $\mathrm{C}$ at all passages.

Protein concentration was measured in the freeze-thaw extract of the three independent cell cultures from flasks seeded at 3000 cells $/ \mathrm{cm}^{2}$ from passages 2, 6, 10 and 15 . Protein concentration is represented from one million cells from each sub-culture in triplicate \pm standard deviation of the mean. Photos of cells from each cell line at passage 2, 6, 10 and 15 .

\subsection{Biological Activity: Cellular Growth Stimulation Assay}

When added to aged-fibroblasts as target cells, GM01717 and CRL-1221, in cell culture, extracts had a stimulatory effect on the cell growth of GM01717 and CRL-1221 cells but to different extents (Figure 3). Individual cell lines showed a dose-dependent stimulatory effect with CT showing the best effect with both target cell lines but the cell line GM01717 was more sensitive of the two used. When cell-free extracts of the three cell lines were mixed together, there was a symbiotic effect for cellular growth stimulation. The effect was dose-dependent with a 5.5 fold increase in growth stimulation of GM01717 and 3.75 fold increase with CRL-1221 cells seen with combined extracts as compared to controls where only buffer was added. An increase of 1.75 - 2.65 fold stimulation was seen with the combined extracts when compared to extracts from a single tissue. Combinations of two independent extracts were similar to those seen for all three (data not shown).

Extracts were tested individually or combined together (skin, muscle or connective tissue) at various concentrations $(0,12,2.5,3,3.5,4$ and $6 \mu \mathrm{g} / \mathrm{ml})$. Growth stimulation was done with two different adult skin cells used as target cell lines (GM01717 and CRL-1221, 40-year-old males). Data is represented as the number of target skin cells as a function of concentration of progenitor extracts after 4 days of stimulation. Graphs are from three independent experiments.
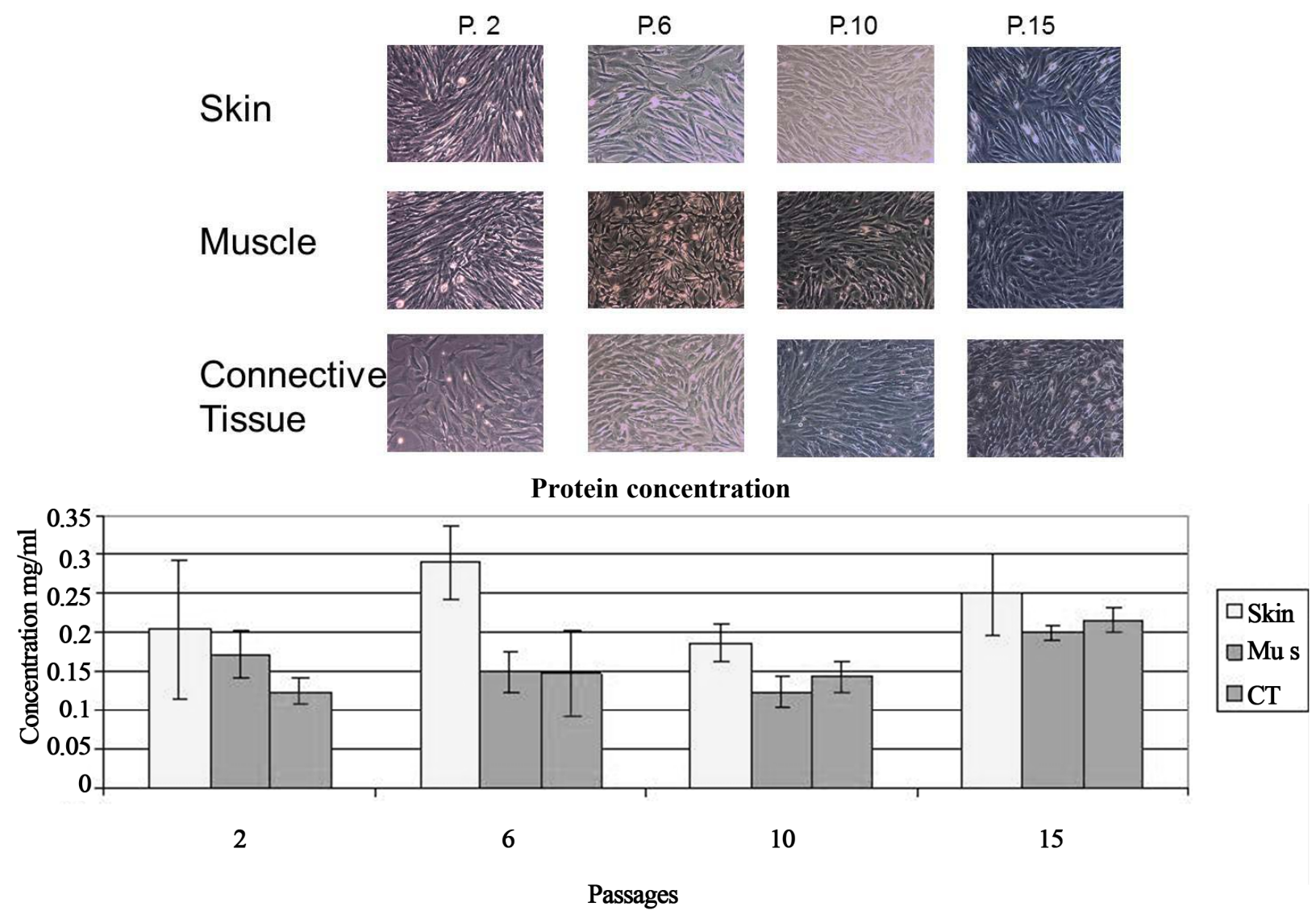

Figure 2. Protein stability of progenitor cells. 
Cell Number $\left(10^{6}\right)$
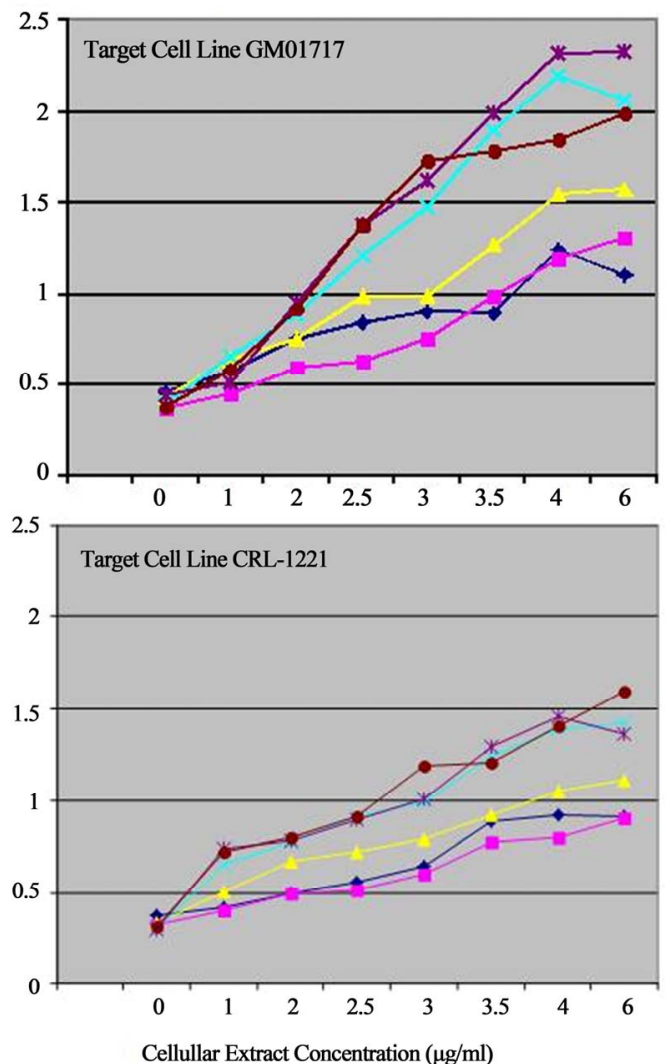

Figure 3. Biostimulation with progenitor cell-free extracts.

\subsection{Assessment of in Vivo Stability of Proteins in Pharmaceutical Cream Preparations}

Cell-free extracts incorporated into cream preparation were both separated by ultra-centrifugation and concentrated by desiccation with silica gel, separated from the cream using a Bio-rad "ReadyPrep clean-up" kit, or extraction by SDS (1\% - 10\%) directly. Proteins were extracted at 2, 4, 6 and 12 months following incorporation into cream base. Protein stability was examined by SDSPAGE electrophoresis on $4 \%-20 \%$ TrisHCL polyacrylimide gels (Biorad, Switzerland).

Separation of proteins by ultra-centrifugation resulted in the liquid phase under the cream phase in the tubes. Fine needles were used to recuperate the liquid from below that was then concentrated by desiccation with silica gel. Using this procedure, the total protein recuperated was inferior than that necessary to visualize most of the MW bands on SDS-PAGE gels. The Bio-Rad "ReadyPrep clean-up" kit did not permit a major amelioration to this aspect. Concentrated pharmaceutical creams (preparations at $170-340 \mu \mathrm{g} / \mathrm{ml}$ of total protein) were then subjected to a direct extraction with $1 \%$ SDS, frozen, centrifuged and loaded onto SDS-PAGE gel for separation (Figure 4). The MW of proteins remained as large as those seen in extracts not incorporated into cream (lanes 2, 3 and 6,8) and were easily separated under the conditions employed. MW of proteins was mainly between 20 - $60 \mathrm{kDa}$ (Figure 4).

Cellular extracts were incorporated into and oil-in water cream to give $170-340 \mu \mathrm{g} / \mathrm{ml}$ of total protein. Protein extraction by SDS (10\%) was at 1 year (cream kept at $22^{\circ} \mathrm{C}$ ) followed by SDS-PAGE electrophoresis on $4 \%$ $20 \%$ TrisHCL polyacrylimide gel in triplicate. Column one and four are molecular weight markers, columns 2 and 6 are proteins extracted from cream $(\mathrm{C} 1, \mathrm{C} 2)$ and columns 3 and 8 are proteins that were kept at $22^{\circ} \mathrm{C}$ for one year (E1, E2).

\subsection{Preliminary Assessment of Pharmaceutical Cream Preparation}

In vivo tests were accomplished on wounds and burns of animals and humans that presented to the Pharmacy setting (Figures 5 and 6). The wounds were photographed and then a thin layer of pharmaceutical cream, with optimized concentrations of cell-free extracts $(6 \mu \mathrm{g} / \mathrm{ml})$, was applied to the wound or burn. For human patients, a gauze bandage was placed for protection but animal cases did not permit this anatomically. For veterinary cases, cow udders are routinely walked on by other cows and ulcerations occur which can last several months which result in not being able to obtain milk from the injured udder or complete loss (amputation necessary). Rapid closure is necessary and it is usually difficult to observe such a wound in time to suture the udder in place.

\subsubsection{Veterinary Cases}

Case 1 represents a cow udder which was resistant to all other therapies since one month (veterinary cream, honey, lotions) and continued to be rigid throughout the udder tip (Figure 5). Following 2 weeks of daily Pharmaceutical cream application, obvious wound closure was no-

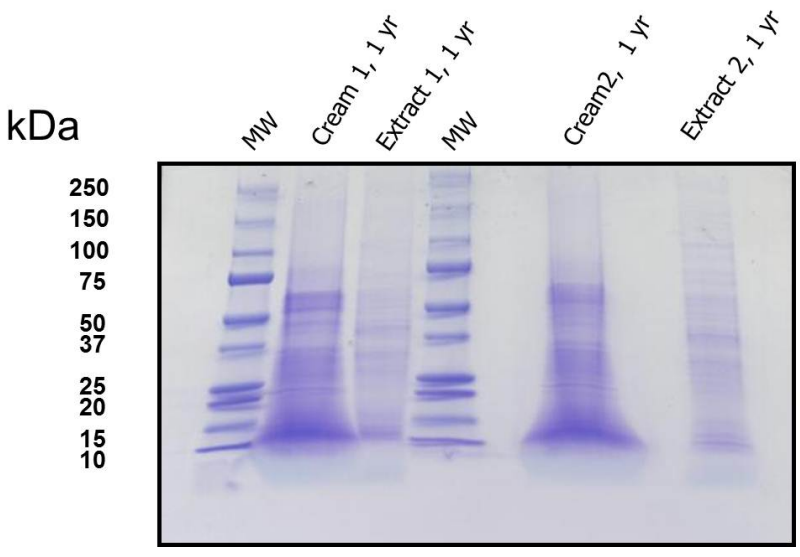

Figure 4. SDS-PAGE gel with separated proteins. 
ticed and milking was possible. Ulceration repaired progressively and the udder became supple even though cream application was one time a day with no possibility to cover and protect the wound with bandages. Case 2 represents a cow udder that was not sutured in time and was suspending from the cow (Figure 5). Pharmaceutical cream was applied once daily for 4 weeks and milking could resume following 1 week already. Progressive closure of this very large wound was possible with very little scar tissue present (Figure 5, photo 9 weeks).

\subsubsection{Patient Cases}

Patient 1 (Figure 6) represents a wound which, if had been presented immediately to a doctor, would have required sutures. The patient came only 4 days following the accident of falling on a glass which produced a wound $(1.5 \times 3 \mathrm{~cm})$ with raised borders. Epithelization was seen as soon as 2 days of daily cream application. Following 1 week, the wound was flat with no inflammation and a thin epidermis evident throughout.

Patients 2 and 3 represent burn wounds of different degrees (Figure 6). Patient 2 presented with a second degree burn with blistering one week following a battery acid accident. Pharmaceutical cream was placed only at days 1, 2, 6 and 10 (4 applications total) with outer bandage application for protection. Outer dead skin was sloughed following the first application of cream (seen at day 2) with new epitheliazation already seen on the border of the burned tissue. Full elasticity with very little scarring was seen at 30 days following the burn. Patient 3 (Figure 6) presented with a localized solder burn which typically leaves an undesirable scar. Pharmaceutical cream was applied 1 - 2 times daily for 10 days with no outer bandage. Following 6 days, all blistering was eliminated and no scar was visible at three month follow-up.

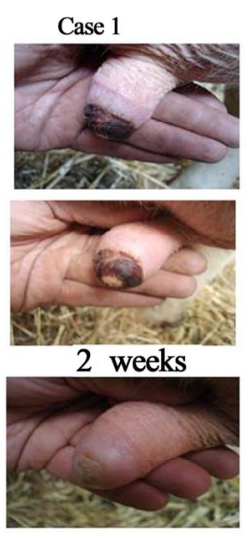

7 weeks

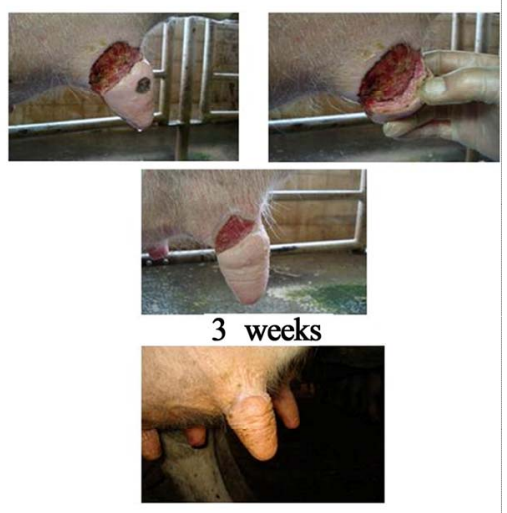

9 weeks
Figure 5. Veterinary cases: cows presenting with udder ulcerations. Case 1 -representing a chronic lesion since 2 months and resistant to other treatments. Case 2-representing a detached udder which could provide milk within 6 days following daily cream application.
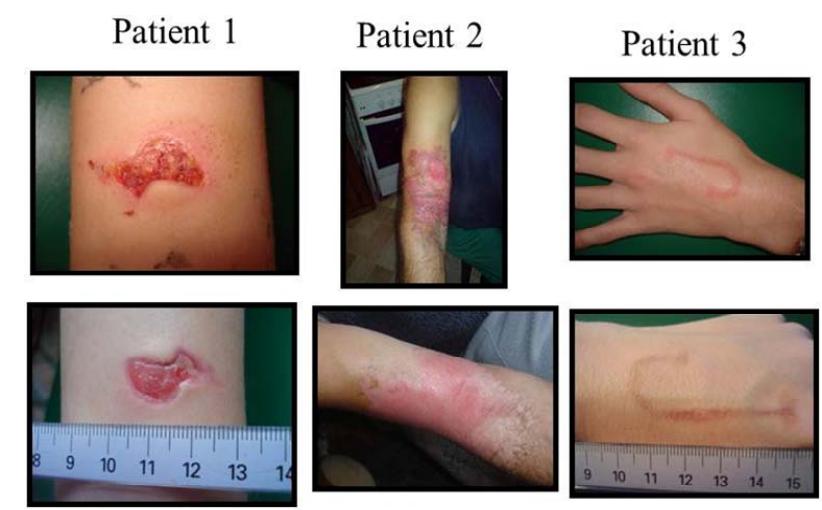

6 days

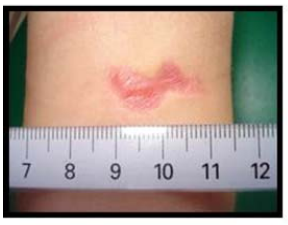

2 weeks
7 days

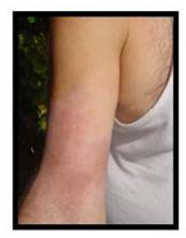

4 weeks
6 days

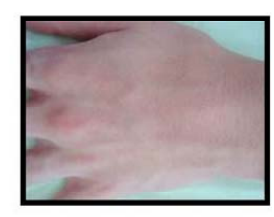

6 weeks
Figure 6. Patients with various forms of acute wounds (Patient 1) glass incision (Patient 2) acid burn; and (Patient 3) wire solder burn treated with pharmaceutical preparations. Evolution of wounds early in treatment with bandage changes every 2 days illustrates rapid wound repair with low associated inflammation.

\section{Discussion}

Ovine cells show qualities required for the establishment of cell banks to be used for production of cell-free derivatives for cosmeceutical and/or medicinal products. Many medicinal products use tissue sources as starting material and one of the major uses of porcine intestine is primary tissue source for insulin production world-wide. The development of one cell source from cell culture has advantages as starting material when developing derivative products. Similarly, many vaccines are developed with the use of defined progenitor cell lines. The Nobel Prize for Medicine in 1954 was awarded to American Immunologists who developed the polio vaccine based on cultures of human fetal or progenitor cells. Since this time, many other necessary vaccines (rubella, chicken pox, hepatitis A, etc.) have been developed with the use of progenitor cell lines including two primary human diploid cell lines which were originally prepared in the 1960's. The first cell line, WI-38 (Wistar Institute 38) was developed by Leonard Hayfleck in 1964 from fetal tissue from a voluntary pregnancy interruption and later given the ATCC (American Type Culture Collection) number of CCL-75. This cell line was used for the historical production of vaccine RA 27/3 against rubella.

The second cell line was the MRC-5 (Medical Research Council 5) from a 14 week gestation male fetal lung tissue donated following a voluntary pregnancy interruption developed in 1966. This cell line has actively 
produced vaccines for chickenpox, hepatitis A, polio, smallpox and rabies. There are other cell lines that have been developed in the 1970's that are actively used for pharmaceutical needs such as the PER.C6 fetal cell line developed from 18 week gestation retinal tissue primarily for the manufacturing of adenovirus vectors for gene therapy and for developmental stage vaccines including Ebola virus, influenza, Japanese encephalitis and HIV. It should be mentioned that alternative vaccine production using animal cells and tissues have been established but the same efficacy and safety have not been confirmed. For example chicken embryos were used to develop vaccines for mumps, measles and rabies and serious allergies occurred upon administration as there is a high percentage of population allergic to this animal source. To date, there are no options in the US for vaccination against rubella, chickenpox and hepatitis A which are produced using both the WI-38 and MRC-5 human fetal cell lines established in the 1960's. It is evident that fetal or progenitor cells have very special qualities that can assure efficacy and safety that is necessary for universal use of therapeutic agents. The source of material, the age and the processing can help in safety aspects of derivative production development. $\mathrm{MCB}$ and $\mathrm{WCB}$ have been prepared from progenitor skin tissue in short periods of time compared to other primary cells for human source tissue [17] and processing has now been shown herein to be more efficient with animal progenitor cells. The lifespan and the proliferation rate of the ovine cells allowed to build master cell banks of 100 ampoules containing 4 - 5 millions cells each from $1 \mathrm{~cm}^{2}$ of tissue at very early passaging (Passage 1 ) and in half the time compared to human cell sources. Cell counts and protein determination analysis are useful tools to assess the consistency of the cell banks. A functional assay showing significant biological activity of the final cell-free product will rely on the activity of the cell proteome. Furthermore activity of the final product is likely to be due to synergistic effects of multiple proteins, which can not be assessed by individual protein concentration or activity.

It was Coulomb et al. [26,27] who first found that co-culture of skin cells were an advantage for tissue engineering purposes. Since this, other applications with co-culture of other cells have also shown synergy such as for bone and cartilage [28-30]. Similarly, we have seen herein that cells that have been co-cultured from the skin, muscle and connective tissue show additive effects for stimulation of cell growth (target cells) further establishing that co-culture is important for topical skin preparations for aiding in wound healing. When cell-free derivatives were added to cream formulations, stable preparations could be developed. Very low concentrations of cell-free extracts could be shown to be beneficial to hydrating creams for minor burns and wounds and helped to keep the wound sites moist during the full repair process of tissue. Other Pharmaceutical preparations available for the same indications used routinely in Switzerland and Europe are Flamazine ${ }^{\circledR}$ which contains sulfadiazine used for small burns and wounds and cutaneous infections. Ialugen ${ }^{\circledR}$ and Ialugen plus ${ }^{\circledR}$ contain hyaluronic acid to permit wound healing with anti-inflammatory effects and the latter contains an anti-bacterial agent (silver sulfadiazine). The advantage of cell-free extracts is that there is no need for a chemical "active ingredient" for topical skin care and wound healing and more simple delivery systems of hydrogels could be implemented. Overlall, biological preparations with ovine progenitor cell-free extracts show potential for topical applications for skin affections and most importantly when cells are co-cultured.

\section{Acknowledgements}

This study was accomplished for the Masters Degree of Pharmaceutical Sciences for the first author (AL) where interaction with Industrial Pharmacy is encouraged. We thank Prof. Michel Monod for help in protein separation methods, Dr. Nathalie Hirt-Burri for help with the illustrations and Dr. Laurent Guillemot for suggestions and corrections in the manuscript.

\section{REFERENCES}

[1] A. Limat, D. Mauri and T. Hunziker, "Successful Treatment of Chronic Leg Ulcers with Epidermal Equivalents Generated from Cultured Autologous Outer Root Sheath Cells," Journal of Investigative Dermatology, Vol. 107, No. 1, 1996, pp. 128-135. doi:10.1111/1523-1747.ep12298415

[2] P. Bianco and P. G. Robey, "Stem Cells in Tissue Engineering," Nature, Vol. 414, No. 6859, 2001, pp. 118-122. doi: $10.1038 / 35102181$

[3] K. M. Bullard, M. T. Longaker and H. P. Lorenz, "Fetal Wound Healing: Current Biology," World Journal of Surgery, Vol. 27, No. 1, 2003, pp. 54-61. doi:10.1007/s00268-002-6737-2

[4] A. Kaviani, T. Perry, A. Dzakovic, R. W. Jennings, M. M. Ziegler and D. O. Fauza, "The Amniotic Fluid as a Source of Cells for Fetal Tissue Engineering," Journal of Pediatric Surgery, Vol. 36, No. 11, 2001, pp. 1662-1665. doi:10.1053/jpsu.2001.27945

[5] A. Kaviani, T. Perry, C. M. Burnes, J.-T. Oh, M. M. Ziegler, S. J. Fishman and D. O. Fauza, "The Placenta as a Cell Source in Fetal Tissue Engineering," Journal of Pediatric Surgery, Vol. 37, No. 7, 2002, pp. 995-999. doi:10.1053/jpsu.2002.33828

[6] C.-H. Wu, G.-Y. Chang, C.-T. Hsu and R.-S. Chen, "Wound Healing Effects of Porcine Placental Extracts on Rats with Thermal Injury," British Journal of Dermatology, Vol. 148, No. 2, 2003, pp. 236-245. doi:10.1046/j.1365-2133.2003.05164.x 
[7] S. R. Beanes, F. Y. Hu, C. Soo, C. M. Dang, M. Urata, K. Ting, J. B. Atkinson, P. Benhaim, M. H. Hedrick and H. P. Lorenz, "Confocal Microscopic Analysis of Scarless Repair in the Fetal Rat: Defining the Transition," Plastic and Reconstructive Surgery, Vol. 109, No. 1, 2002, pp. 160-170. doi:10.1097/00006534-200201000-00026

[8] R. E. Fitzpatrick and E. F. Rostan, "Reversal of Photodamage with Topical Growth Factors: A Pilot Study," Cosmetic and Laser Therapy, Vol. 5, No. 1, 2003, pp. 25-34 doi:10.1080/14764170310000817

[9] M. H. Gold, M. P. Goldman and J. Biron, "Efficacy of Novel Skin Cream Containing Mixture of Human Growth Factors and Cytokines for Skin Rejuvenation," Journal of Drugs Dermatology, Vol. 6, No. 7, 2007, pp. 197-201.

[10] M. H. Gold and J. Biron, “A Novel Skin Cream Containing a Mixture of Human Growth Factors and Cytokines for the Treatment of Adverse Events Associated with Photodynamic Therapy," Journal of Drugs Dermatology, Vol. 5, 2006, pp. 796-798.

[11] D. L. Cass, M. Meuli and N. S. Adzick, "Scar Wars: Implications of Fetal Wound Healing for the Pediatric Burn Patient," Journal of Pediatric Surgery, Vol. 12, No. 7, 1997, pp. 484-489. doi:10.1007/BF01258707

[12] J. R. Armstrong and M. W. J. Ferguson, "Ontogeny of the Skin and the Transition from Scar Free to Scarring Phenotype during Wound Healing in the Pouch Young of the Marsupial Monodelphis domestica," Developmental Biology, Vol. 169, No. 1, 1995, pp. 242-260. doi:10.1006/dbio.1995.1141

[13] C. Dang, K. Ting, C. Soo, M. T. Longaker and H. P. Lorenz, "Fetal Wound Healing Current Perspectives," Clinics in Plastic Surgery, Vol. 30, No. 1, 2003, pp. 13-23. doi:10.1016/S0094-1298(02)00067-6

[14] J. Hohlfeld, A. de Buys Roessingh, N. Hirt-Burri, P. Chaubert, S. Gerber, C. Scaletta, P. Hohlfeld and L. A. Applegate, "Tissue Engineered Fetal Skin Constructs for Paediatric Burns," Lancet, Vol. 366, No. 9488, 2005, pp. 840-842. doi:10.1016/S0140-6736(05)67107-3

[15] A. de Buys Roessingh, J. Hohlfeld, J. Scaletta, N. Hirt-Burri, S. Gerber, P. Hohlfeld, J.-O. Gebbers and L. A. Applegate, "Development, Characterization and Use of a Fetal Skin Cell Bank for Tissue Engineering in Wound Healing," Cell Transplantation, Vol. 15, No. 8-9, 2006, pp. 823-834. doi:10.3727/000000006783981459

[16] A.-A. Ramelet, N. Hirt-Burri, W. Raffoul, Scaletta, D. P. Pioletti, E. Offord, R. Mansourian and L. A. Applegate, "Chronic Wound Healing by Fetal Cell Therapy may be Explained by Differential Gene Profiling Observed in Fetal Versus Old Skin Cells," Experimental Gerontology, Vol. 44, No. 3, 2009, pp. 208-218.

[17] A. Quintin, N. Hirt-Burri, C. Scaletta, C. Schizas, D. Pioletti and L. A. Applegate, "Consistency and Safety of Fetal Cell Banks for Research and Clinical Use: Preliminary Analysis of Fetal Skin Banks," Cell Transplantation, Vol. 16, No. 7, 2007, pp. 675-684.

[18] N. Hirt-Burri, C. Scaletta, S. Gerber, D. Pioletti and L. A. Applegate, "Wound Healing Gene-Family Expression Differences between Fetal and Foreskin Cells Used for Bioengineered Skin Substitutes," Artificial Organs, Vol. 32,
No. 7, 2008, pp. 509-518.

[19] A. R. Mire-Sluis, "Progress in the Use of Biological Assays during the Development of Biotechnology Products," Pharmaceutical Research, Vol. 18, No. 9, 2010, pp. 1239-1246.

[20] M. P. Curran and G. L. Plosker, "Bilayered Bioengineered Skin Substitute (Apligraf): A Review of Its Use in the Treatment of Venous Leg Ulcers and Diabetic Foot Ulcers," BioDrugs, Vol. 16, No. 6, 2002, pp. 439-455. doi:10.2165/00063030-200216060-00005

[21] Y. Kuroyanagi, N. Yamada, R. Yamashita and E. Uchinuma, "Tissue-Engineered Product: Allogeneic Cultured Dermal Substitute Composed of Spongy Collagen with Fibroblasts," Artificial Organs, Vol. 25, No. 3, 2001, pp. 180-186. doi:10.1046/j.1525-1594.2001.025003180.x

[22] M. Fimiani, E. Pianigiani, F. C. Di Simplicio, P. Sbano, A. Cuccia, G. Pompella, G. De Aloe and F. Petaglia, "Other Uses of Homologous Skin Grafts and Skin Bank Bioproducts," Clinics in Dermatology, Vol. 23, No. 4, 2005, pp. 396-402. doi:10.1016/j.clindermatol.2004.07.025

[23] K. W. Ng, H. L. Khor and D. W. Hutmacher, "In Vitro Characterization of Natural and Synthetic Dermal Matrices Cultured with Human Dermal Fibroblasts," Biomaterials, Vol. 25, No. 14, 2004, pp. 2807-2818. doi:10.1016/j.biomaterials.2003.09.058

[24] V. Falanga, D. Margolis, O. Alvarez, M. Auletta, F. Maggiacomo, M. Altman, J. Jensen, M. Sabolinski, J. Hardin-Young and the Human Skin Equivalent Investigators Group, "Rapid Healing of Venous Ulcers and Lack of Clinical Rejection with an Allogeneic Cultured Human Skin Equivalent," Archives of Dermatology, Vol. 134, No. 3, 1998, pp. 293-300. doi:10.1001/archderm.134.3.293

[25] P. Waymack, R. G. Duff, M. Sabolinski and The Apligraf Burn Study Group, "The Effect of a Tissue Engineered Bilayered Living Skin Analog, over Meshed Split-Thickness Autografts on the Healing of Excised Burn Wounds," Burns, Vol. 26, No. 7, 2000, pp. 609-619. doi:10.1016/S0305-4179(00)00017-6

[26] B. Coulomb, C. Lebreton and L. Dubertret, "Influence of Human Dermal Fibroblasts on Epidermalization," Journal of Investigative Dermatology, Vol. 92, No. 1, 1989, pp. $122-125$.

[27] B. Coulomb, L. Friteau, J. Baruch, J. Guilbaud, B. Chretien-Marquet, J. Glicentstein, C. Lebreton-Decoster, E. Bell and L. Dubertret, "Advantage of the Presence of Living Dermal Fibroblasts within in Vitro Reconstructed Skin for Grafting in Humans," Plastic and Reconstructive Surgery, Vol. 101, No. 7, 1998, pp. 1891-1903. doi:10.1097/00006534-199806000-00018

[28] H. A. Rackhorst, S. J. Posthumus-van Sluijs, M. W. Wendy, J. W. Van Neck, G. J. V. M. Van Osch, S. E. R. Hovius, A. Ghalbzouri and S. O. P. Hofer, "Fibroblasts Accelerate Culturing of Mucosal Substitutes," Tissue Engineering, Vol. 12, No. 8, 2006, pp. 2321-2331. doi:10.1089/ten.2006.12.2321

[29] D. Nikolidakis, J. Van den Dolder, J. G. C. Wolke, P. J. W. Stoelinga and J. A. Jansen, "The Effect of PlateletRich Plasma on the Bone Healing around Calcium Phosphate-Coated and Non-Coated Oral Implants in Trabecu- 
lar Bone," Tissue Engineering, Vol. 12, No. 9, 2006, pp. 2555-2563. doi:10.1089/ten.2006.12.2555

[30] R. Nakoaka, S. X. Hsiong and D. J. Mooney, "Regulation of Chondrocyte Differentiaion Level via Co-Culture with Osteoblasts," Tissue Engineering, Vol. 12, No. 9, 2006, pp. 2425-2433. doi:10.1089/ten.2006.12.2425 